\title{
Targeted nanotherapeutics in cancer
}

This article was published in the following Dove Press journal:

International Journal of Nanomedicine

26 March 2014

Number of times this article has been viewed

\section{Farooq A Shiekh}

Avalon University School of Medicine, Curaçao, Netherlands Antilles
Correspondence: Farooq A Shiekh Avalon University School of Medicine, Scharlooweg 25, Curaçao, Netherlands Antilles

Email shiekh.fa@gmail.com

\section{Targeted nanotherapeutics in cancer}

Cancer is not one, but many heterogeneous diseases ${ }^{1}$ with complex genetic and epigenetic alterations ${ }^{2,3}$ that annually afflict millions of people worldwide. Despite the progress in understanding the molecular mechanics of cancer, ${ }^{4}$ its treatment has remained essentially unchanged and the death rates almost remain as they were 6 decades ago. ${ }^{5,6}$ In the past, the outstanding failure to deliver effective treatment to patients was a result of the inability to get enough of the right drug to the right place; however, the scenario has started to change substantially with the advent of new "targeted" cancer therapies. ${ }^{7-10}$

The field of drug delivery is a powerful concept in cancer therapy, which is advancing rapidly. Notably, the emerging new genomic knowledge has revolutionized molecular medicine,${ }^{11}$ and targeting with antibody therapeutics ${ }^{6,12}$ and siRNA holds great promise as a potential new class of therapeutics with an ability to treat complex tumor types ${ }^{13,14}$ that have, thus far, been resistant to available therapies. However, the lack of identified molecular biomarkers that could fully explain epigenetic changes and the heritability of complex tumors, ${ }^{15}$ making it very difficult for target recognition and treatment, ${ }^{16}$ should benefit from vigorous target validation ${ }^{17,18}$ and other efforts ${ }^{19-23}$ to develop new targeted drugs. The goal has to be to hit multiple targets simultaneously, so that the devastating tumor cannot develop resistance. Compelling evidence highlights the potential of advanced nanocarriers ${ }^{14,24}$ as combination multitherapeutic platforms for enhanced efficacy against aggressive cancer cell types..$^{20,21,25}$ These combinations have the potential to significantly eliminate the amount of cytotoxic chemotherapy used, which is still currently the backbone of most oncology treatments.

Personalized nanomedicine has the potential to address one of the biggest problems in cancer therapy: how to get enough of the right combination of therapeutics to the right place, which represents a new paradigm shift in advanced technology; this may prove to be the first cutting-edge field to reflect the new realities of targeted medicine. The hope is that interventions can be tailored to maximize patient benefit with fewer side effects. However, many outstanding challenges remain.

\section{Acknowledgments}

I would like to acknowledge Dr Shokat Fatteh (Ohio, USA) and the Avalon Research Committee for their research support. 


\section{Disclosure}

The author reports no conflicts of interest in this work.

\section{References}

1. Marte B. Tumour heterogeneity. Nature. 2013;501(7467):327.

2. Kircher M, Witten DM, Jain P, O'Roak BJ, Cooper GM, Shendure J. A general framework for estimating the relative pathogenicity of human genetic variants. Nat Genet. Epub February 2, 2014.

3. Suvà ML, Riggi N, Bernstein BE. Epigenetic reprogramming in cancer. Science. 2013;339(6127):1567-1570.

4. Seyfried TN, Flores RE, PoffAM, D'Agostino DP. Cancer as a metabolic disease: implications for novel therapeutics. Carcinogenesis. Epub January 20, 2014.

5. Sliwkowski MX, Mellman I. Antibody therapeutics in cancer. Science. 2013;341(6151):1192-1198.

6. Service RF. Materials and biology. Nanotechnology takes aim at cancer. Science. 2005;310(5751):1132-1134.

7. Katsnelson A. Drug development: target practice. Nature. 2013;498(7455):S8-S9.

8. Katsnelson A. Momentum grows to make 'personalized' medicine more 'precise'. Nat Med. 2013;19(3):249.

9. Vilella A, Tosi G, Grabrucker AM, et al. Insight on the fate of CNStargeted nanoparticles. Part I: Rab5-dependent cell-specific uptake and distribution. J Control Release. 2014;174:195-201.

10. Tosi G, Ruozi B, Belletti D, et al. Brain-targeted polymeric nanoparticles: in vivo evidence of different routes of administration in rodents. Nanomedicine (Lond). 2013;8(9):1373-1383.

11. McCarthy JJ, McLeod HL, Ginsburg GS. Genomic medicine: a decade of successes, challenges, and opportunities. Sci Transl Med. 2013;5(189):189sr4

12. Shiekh FA. Blood-brain barrier: a real obstacle for therapeutics. Int $J$ Nanomedicine. 2012;7:4065-4066.

13. Davis ME, Zuckerman JE, Choi CH, et al. Evidence of RNAi in humans from systemically administered siRNA via targeted nanoparticles. Nature. 2010;464(7291):1067-1070.
14. Bigini P, Previdi S, Casarin E, et al. In vivo fate of avidin-nucleic acid nanoassemblies as multifunctional diagnostic tools. ACS Nano. 2014;8(1):175-187.

15. Riddihough G, Zahn LM. Epigenetics. What is epigenetics? Introduction. Science. 2012;330(6004):611.

16. Sun X, Vilar S, Tatonetti NP. High-throughput methods for combinatorial drug discovery. Sci Transl Med. 2013;5(205):205rv1.

17. Martinez Molina D, Jafari R, Ignatushchenko M, et al. Monitoring drug target engagement in cells and tissues using the cellular thermal shift assay. Science. 2013;341(6141):84-87.

18. Gibbs JB. Mechanism-based target identification and drug discovery in cancer research. Science. 2000;287(5460):1969-1973.

19. Guo S, Miao L, Wang Y, Huang L. Unmodified drug used as a material to construct nanoparticles: delivery of cisplatin for enhanced anti-cancer therapy. J Control Release. 2014;174:137-142.

20. Tagalakis AD, Kenny GD, Bienemann AS, et al. PEGylation improves the receptor-mediated transfection efficiency of peptidetargeted, self-assembling, anionic nanocomplexes. J Control Release. 2014;174:177-187.

21. Kenny GD, Bienemann AS, Tagalakis AD, et al. Multifunctional receptor-targeted nanocomplexes for the delivery of therapeutic nucleic acids to the brain. Biomaterials. 2013;34(36):9190-9200.

22. Tiwari SK, Agarwal S, Seth B, et al. Curcumin-loaded nanoparticles potently induce adult neurogenesis and reverse cognitive deficits in Alzheimer's disease model via canonical Wnt/beta-catenin pathway. ACS Nano. 2014;8(1):76-103.

23. Shiekh FA. Personalized nanomedicine: future medicine for cancer treatment. Int J Nanomedicine. 2013;8:201-202.

24. Bourzac K. Nanotechnology: carrying drugs. Nature. 2012;491(7425): S58-S60.

25. Deng ZJ, Morton SW, Ben-Akiva E, Dreaden EC, Shopsowitz KE, Hammond PT. Layer-by-layer nanoparticles for systemic codelivery of an anticancer drug and siRNA for potential triple-negative breast cancer treatment. ACS Nano. 2013;7(11):9571-9584.
International Journal of Nanomedicine

\section{Publish your work in this journal}

The International Journal of Nanomedicine is an international, peerreviewed journal focusing on the application of nanotechnology in diagnostics, therapeutics, and drug delivery systems throughout the biomedical field. This journal is indexed on PubMed Central, MedLine, CAS, SciSearch ${ }^{\circledR}$, Current Contents ${ }^{\circledR} /$ Clinical Medicine,

\section{Dovepress}

Journal Citation Reports/Science Edition, EMBase, Scopus and the Elsevier Bibliographic databases. The manuscript management system is completely online and includes a very quick and fair peer-review system, which is all easy to use. Visit http://www.dovepress.com/ testimonials.php to read real quotes from published authors. 